\title{
Characterization and Isolation of Thyroid Microsomal Antigen
}

\author{
Noboru Hamada, Luc Portmann, and Leslie J. DeGroot \\ Thyroid Study Unit, Department of Medicine, The University of Chicago, Chicago, Illinois 60637
}

\begin{abstract}
We investigated the structure of the 107-kD thyroid protein recognized as microsomal antigen. Solubilized microsomes were incubated with affinity gels consisting of IgG, from thyroiditis patients or controls, linked to Reacti-gel. Eluates were analyzed by SDS polyacrylamide electrophoresis and Western blot. 107and 101-kD proteins were augmented in eluates from gels containing patient IgG and had microsomal antigenicity. In a Western blot of microsomes run under unreduced conditions, poorly defined large proteins were identified by antibody. When eluted electrophoretically and reanalyzed in reducing conditions, they demonstrated the $107-\mathrm{kD}$ antigen. The $107-\mathrm{kD}$ protein identified in reducing conditions was extracted and reanalyzed under nonreducing conditions. Large molecular mass proteins were then observed. On two-dimensional electrophoresis, a 107-kD antigen was isolated with isoelectric point of 7.0. The microsomal antigen may be complexes or multimers of a $107-\mathrm{kD}$ peptide with isoelectric point of 7.0.
\end{abstract}

\section{Introduction}

Antibodies to thyroid microsomal antigen are considered to be active in the pathogenesis of autoimmune thyroid disease (AITD) ${ }^{1}$ by binding to the thyroid cell surface $(1,2)$ and causing cell damage $(3,4)$. The exact nature of the antigen is uncertain, although it is known to be an organ-specific protein bound to the vesicle transporting newly synthesized thyroglobulin (5) and is present in high concentration in thyrotoxic glands (6). Recently we found by Western blotting and immunoprecipitation using sera of patients with AITD that a $107-\mathrm{kD}$ protein from thryoid microsomes is a thyroid microsomal antigen, and that it may be associated with another protein or maintain a unique conformation due to disulfide bonds present in the native state (7). It was surprising that only one protein could be identified as a microsomal antigen, although this protein appeared to resolve into double bands of nearly equal molecular mass in some Western blot studies. Our previous study raised several questions. (a) Does the microsomal antigen consist of only the $107-\mathrm{kD}$ protein or does it contain other proteins? $(b)$ Do the poorly defined large molecular mass proteins, demonstrated to have mi-

Address all correspondence to Dr. De Groot, Professor of Medicine, Thyroid Study Unit, Box 138, The University of Chicago, 5841 South Maryland Avenue, Chicago, IL 60637.

Received for publication 27 June 1986.

1. Abbreviations used in this paper: 2-DG, two-dimensional gel; AITD, autoimmune thyroid disease; IF, isoelectric focusing; pI, isoelectric point.

J. Clin. Invest.

(c) The American Society for Clinical Investigation, Inc.

0021-9738/87/03/0819/07 \$1.00

Volume 79, March 1987, 819-825 crosomal antigenicity in Western blots run under unreduced conditions, contain the $107-\mathrm{kD}$ protein? $(c)$ Is the second band associated with the $107-\mathrm{kD}$ protein another specific protein or a catabolite of the $107-\mathrm{kD}$ protein? (d) Can the $107-\mathrm{kD}$ antigenic protein be purified? This study was undertaken to answer these questions.

\section{Methods}

Preparation of microsomes. Microsomes were prepared by differential centrifugation (8) from frozen surgical specimens of toxic-diffuse goiters from blood group $O$ patients, as reported previously (7). Protein concentration was determined by the modified methods of Lowry et al. $(9,10)$.

Solubilization of microsomes. Microsomes $(10 \mathrm{mg})$ were solubilized in $3 \mathrm{ml}$ of phosphate-buffered saline (PBS) containing $1 \%$ Triton X-100 for $30 \mathrm{~min}$ at room temperature using an end-over-end mixer. The mixture was centrifuged at $105,000 \mathrm{~g}$ for $60 \mathrm{~min}$ at $4^{\circ} \mathrm{C}$, and the supernatant was used as solubilized microsomes.

Serum samples. Sera with antithyroid microsomal antibody titers $>20,480$ by the microsomal hemagglutination test and negative antithyroglobulin antibody by the $\mathrm{Tg}$ hemagglutination test were obtained from two patients (L.H. and D.A.) with Hashimoto's disease. L.H. corresponds to patient 1 in our previous report and her serum has antibodies against denatured microsomal antigen. Serum from patient D.A. does not contain this antibody. For uniformity in this investigation, only these two sera were used. They are, however, representative of many other sera from patients with AITD that provide similar results in immunological studies. Serum from one volunteer without thyroid disease and without antithyroid antibodies served as a control. Thyroid-stimulating hormone receptor antibodies measured using kits prepared by R.S.R. Ltd. (Cardiff, U.K.) were negative in both experimental sera.

Enzyme-linked immunosorbent assay (ELISA). ELISA was performed by a modification (7) of the method reported by Schardt et al. (11).

Affinity chromatography. Immuno-affinity gels were prepared using Reacti-gel (6X) (Pierce Chemical Co., Rockford, IL) as described previously (7).

SDS Polyacrylamide Gel Electrophoresis (PAGE). SDS PAGE was based on the method of Victor et al. (12), as described previously (7). Microsomes were heated for $15 \mathrm{~min}$ at $65^{\circ} \mathrm{C}$ in $0.009 \mathrm{M}$ Tris- $\mathrm{HCl}$ buffer (pH 8.0) containing $2.5 \%$ SDS and $2.25 \mathrm{M}$ urea with or without $5 \% 2$ mercaptoethanol. $6 \%$ or $3.3-20.0 \%$ gradient gels, with $3 \%$ acrylamide stacking gel, were used. Gels were stained with $0.125 \%$ Coomassie Blue R-250, silver staining (13), or were used for Western blotting. Molecular weight protein standards $(200,000-14,300$ mol-wt proteins) were purchased from Bio-Rad Laboratories (Richmond, CA). A ${ }^{14} \mathrm{C}$-methylated protein mixture (Amersham International, Amersham, Buckinghamshire, England) was also used as for molecular weight determination.

Elution of protein from SDS polyacrylamide gels. The gel slices containing the bands of interest were put into a dialysis bag filled with 0.041 $\mathrm{M}$ Tris and $0.040 \mathrm{M}$ boric acid buffer with an approximate $\mathrm{pH}$ of 8.35. Proteins were electroeluted out of gels at $100 \mathrm{~V}$ for $3 \mathrm{~h}$ at $4^{\circ} \mathrm{C}$. After dialysis against distilled water, the liquid surrounding the gel slices was recovered and lyophilized.

Two-dimensional gel (2-DG) electrophoresis. Microsomal proteins were treated according to the method reported by Kaderbhai and Freedman (14). Microsomes (15 mg) were solubilized in $2 \mathrm{ml}$ of $50 \mathrm{mM}$ Tris$\mathrm{HCl}$ ( $\mathrm{pH} 7.5$ ) containing $0.3 \%$ deoxycholate for $30 \mathrm{~min}$ at room temperature. The mixture was centrifuged for $1 \mathrm{~h}$ at $105,000 \mathrm{~g}$, and the 


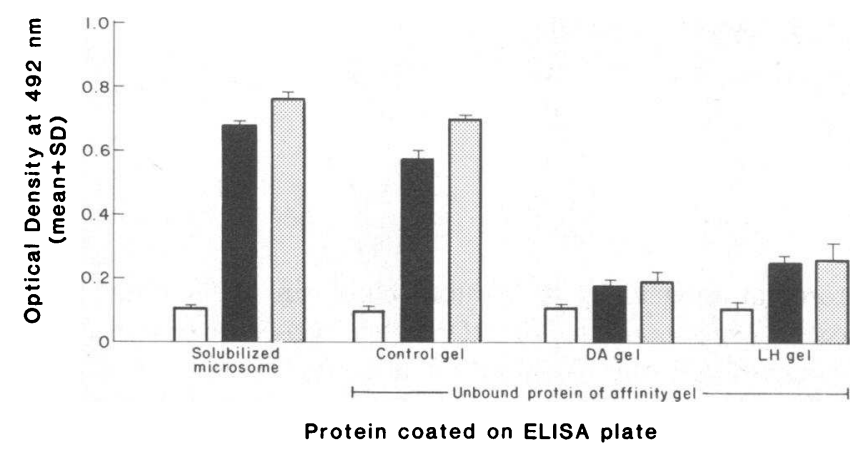

Figure 1. Antigenic activity of microsomal proteins not bound by control, patients D.A. or L.H.'s IgG-linked to Reacti-gel, analyzed by ELISA. $2 \mu \mathrm{g}$ of Triton X-100-solubilized microsomes and proteins not bound by affinity gel were coated on the ELISA plates at $4^{\circ} \mathrm{C}$ overnight. The coated antigen was incubated with a 1:200 dilution of control (open bars), patient D.A.'s (solid bars), and L.H.'s (strippled bars) sera. Results are the mean + SD of triplicate determinations. See details in legend to Fig. 2.

supernatant was dialyzed against $50 \mathrm{ml}$ of $9 \mathrm{M}$ urea and $1 \%$ SDS overnight at room temperature. Immediately before electrofocusing, the sample was diluted with an equal volume of isoelectric focusing sample dilution buffer (15). $40 \mu \mathrm{l}$ of sample containing $90 \mu \mathrm{g}$ of protein were loaded at the basic end. When 107,000-mol-wt protein, extracted from SDS polyacrylamide gel in which microsomes were electrophoresed in reduced condition, was submitted to the first dimension of 2-DG electrophoresis, lyophilized 107,000-mol-wt proteins were dissolved in lysis buffer containing 9.5 M urea, 2\% (wt/vol) Nonidet P-40, 2\% pharmalyte (pH 3$10)$, and 5\% 2-mercaptoethanol.

2-DG electrophoresis under denaturing conditions was carried out according to the method of O'Farrell (15) with the following minor modifications. For the first dimension, Pharmalyte (pH 3-10; Pharmacia Fine Chemicals, Piscataway, NJ) or a combination of 1:5 Pharmalyte (pH 3-10) and Pharmalyte (pH 4-6) was used to make the $\mathrm{pH}$ gradient in the polyacrylamide disk gel. For the second dimension, a $6 \%$ or 3.3$20 \%$ gradient polyacrylamide gel was used. Reduced microsomes treated for SDS PAGE or molecular mass markers were applied to the extremities of the second dimensional gel to serve as markers for the $107-\mathrm{kD}$ proteins.

Western blotting. Proteins resolved by SDS PAGE or 2-DG electrophoresis were electrophoretically transferred onto a nitrocellulose sheet and specific antigenic protein was recognized using ${ }^{125} \mathrm{I}$-protein $\mathrm{A}$ followed by autoradiography (7). $0.01 \mathrm{M}$ Tris- $\mathrm{HCl}(\mathrm{pH} 7.5$ ) plus $0.15 \mathrm{M} \mathrm{NaCl}$ containing $0.3 \%$ Tween 20 was used for washing after incubation with serum.

\section{Results}

Affinity chromatography. $500 \mu \mathrm{g}$ of Triton X-100-solubilized microsomes were incubated with $5 \mathrm{ml}$ of control, patient D.A. or L.H.'s IgG linked to Reacti-gel $(6 \times)$ for $2 \mathrm{~h}$ at room temperature. The unbound fractions were incubated with Bio-Beads SM-2 $(0.3 \mathrm{mg} / \mathrm{ml}$; Bio-Rad Laboratories, Richmond, CA) to remove Triton X-100 (16). The antigenic reactivity of the unbound proteins was compared with equivalent amounts of untreated microsomes, using patient D.A. and L.H.'s and control sera in ELISA assay (Fig. 1). The unbound fractions from affinity

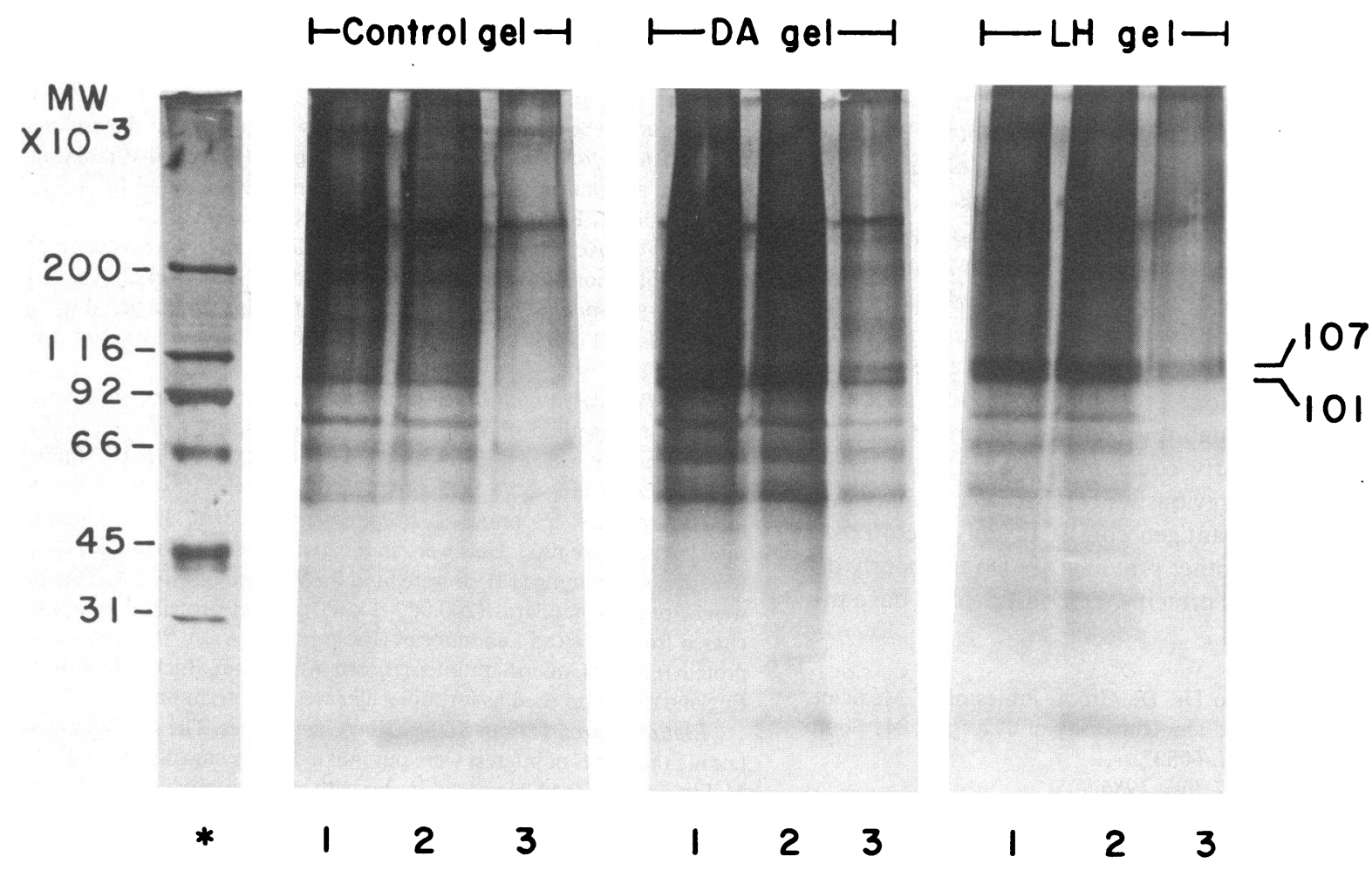

Figure 2. SDS PAGE of microsomal proteins eluted from control, patients D.A. and L.H.'s IgG-linked affinity gel. $500 \mu \mathrm{g}$ of Triton X100-solubilized microsomes was incubated with $5 \mathrm{ml}$ of affinity gel for $2 \mathrm{~h}$ at room temperature. Columns were washed with 40 -column volumes of PBS. Bound material was eluted with $3 \mathrm{M}$ sodium thiocyanate and $5 \mathrm{ml}$ fraction was collected (lanes 1,2 , and 3 indicate frac-

tions 1, 2, and 3), dialyzed against distilled water, lyophilized, and dissolved in $0.009 \mathrm{M}$ Tris- $\mathrm{HCl}$ buffer, $(\mathrm{pH} 8.0)$ containing $2.5 \%$ SDS, $2.25 \mathrm{M}$ urea, and 5\% 2-mercaptoethanol, and heated for $15 \mathrm{~min}$ at $65^{\circ} \mathrm{C}$. All the treated samples were resolved in SDS PAGE $(3.3-20 \%$ linear gradient gel) and gels were stained with silver staining.

* Molecular weight (MW) markers. 
gels of D.A. and L.H.'s IgG were much less antigenic than untreated microsomes, whereas antigenic reactivity of the unbound fraction from a gel made from control IgG was almost the same as that of untreated microsomes. Because Triton X-100-solubilized microsomes have higher antigenic activity than untreated microsomes (in relation to protein concentration) (8) (data not shown), the preparation must contain antigen in its native condition. The $107-\mathrm{kD}$ antigenic protein should bind to the affinity gel in this condition (7), and the protein bound to the affinity gel should contain all the protein components of microsomal antigen. After the gels were washed extensively, the bound proteins were eluted with $3 \mathrm{M}$ sodium thiocyanate (NaSCN), and 5-ml fractions were collected, dialyzed against distilled water, lyophilized, and electrophoresed. As Fig. 2 shows, both eluates from affinity gels made from control and patients' IgG contained numerous proteins identified by silver staining. Most of the proteins in eluates from gels made with patients' IgG were not different from eluates from gels made with normal IgG. Only the 107- and 101-kD proteins were augmented in eluates from patients' gels compared with those from control gels. In addition, Western blot analysis of eluates showed that only the 107- and 101-kD proteins had antigenic activity, and the difference in the amount of specific antigenic proteins, comparing the eluates from control IgG and patient D.A.'s IgG gel, was very large (data not shown). Upon washing with five-column volumes of 0.5 or 1.0 $\mathrm{M}$ NaSCN, 107- and 101-kD proteins become undetectable in eluates from gel made with control IgG, but were still clearly demonstrated in the eluates from the gel made with patients'
IgG by silver staining and Western blot (Fig. 3). These data, together with the results of Western blot and immunoprecipitation of thyroid microsomal proteins reported previously, indicate that all the protein components of microsomal antigen are present as 107 and $101 \mathrm{kD}$ proteins.

Relationship of 107- and 101-kD proteins. The affinity chromatographic study clearly demonstrated two antigenic proteins. Therefore, an investigation was performed to determine whether the $101-\mathrm{kD}$ protein is present in the native condition of microsomal antigen or is a catabolite of the $107-\mathrm{kD}$ protein. Three different microsome preparations were freshly prepared from frozen surgical specimens of toxic diffuse goiter, and analyzed by Western blotting against patient L.H.'s serum. The 107-kD protein was visualized in all three preparations but the $101-\mathrm{kD}$ antigenic protein was not well seen (data not shown). Because Triton X-100-solubilized microsomes were used in the study of affinity chromatography, the effects of solubilization on the 107and 101-kD proteins were investigated. As Fig. $4 a$ shows, the $101-\mathrm{kD}$ protein was more prominent after solubilization. To investigate whether the $101-\mathrm{kD}$ protein is a degradative product of the $107-\mathrm{kD}$ protein, freshly prepared microsomes were incubated at $20^{\circ} \mathrm{C}$ for $2 \mathrm{~h}, 1,2$, and $4 \mathrm{~d}$ and analyzed by SDS PAGE (6\%) and Western blot. No significant change was observed after $2 \mathrm{~h}$, but the 107-kD protein decreased during further incubation. The $101-\mathrm{kD}$ protein was more evident after $1 \mathrm{~d}$ of incubation and was most clearly observed after $2 \mathrm{~d}$ of incubation (Fig. $4 b$, lane $b$ ). Also, in Triton X-100-solubilized microsomes, there was a decrease of $107-\mathrm{kD}$ protein and a slight increase of a

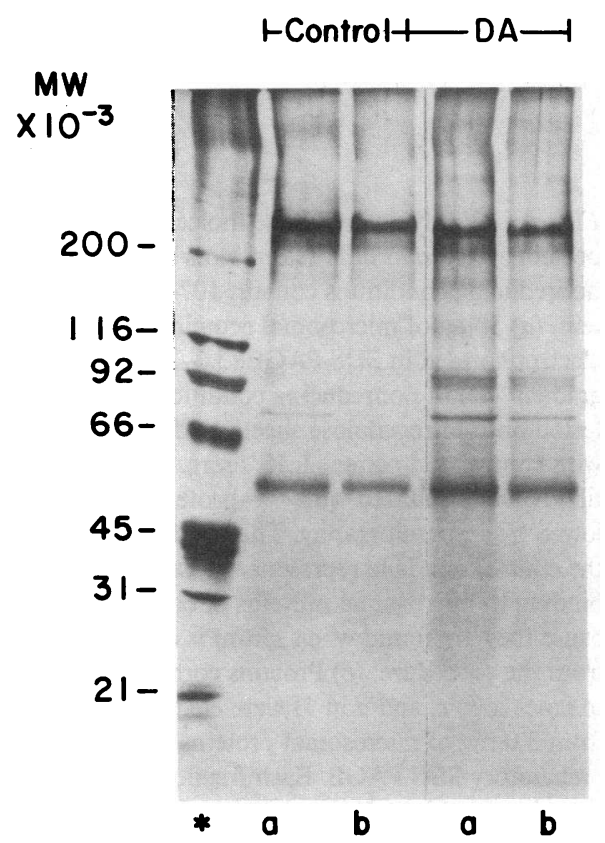

Figure 3. Proteins eluted from control or patient D.A.'s IgG-linked affinity gel, after washing with low concentrations of $\mathrm{NaSCN}$ and analyzed by SDS PAGE and Western blot. $500 \mu \mathrm{g}$ Triton X-100-solubilized microsomes were incubated with $5 \mathrm{ml}$ of affinity gel. After washing with 40-column volumes of PBS containing 0.1\% Triton X-100 and with 40-column volumes of PBS, each column was divided into two. Then, one column $(2.5 \mathrm{ml})$ was washed with five-column volumes of $0.5 \mathrm{M} \mathrm{NaSCN}$ (lanes $a$ ) and another column was washed with

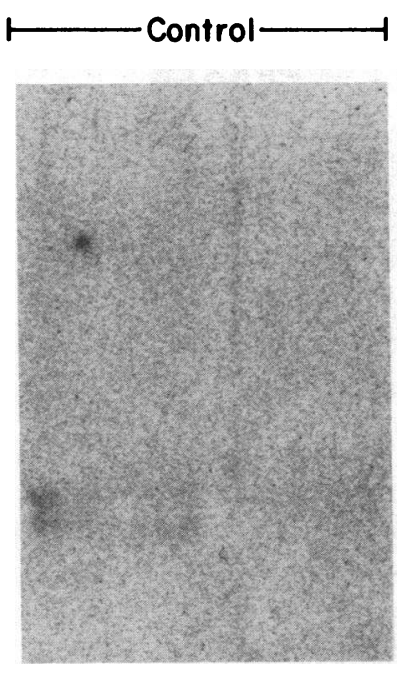

b

five-column volumes of $1.0 \mathrm{M}$ NaSCN (lanes $b$ ). Bound proteins were eluted from both columns with $8 \mathrm{ml}$ of $3 \mathrm{M} \mathrm{NaSCN}$, dialyzed against distilled water, lyophilized, and analyzed in SDS PAGE (3.3-20\%, linear gradient gel) stained with silver staining $(a)$ and Western blotted (b) against patient L.H. serum.

* Molecular weight (MW) markers;-Position of 107- and 101-kD proteins. 
a

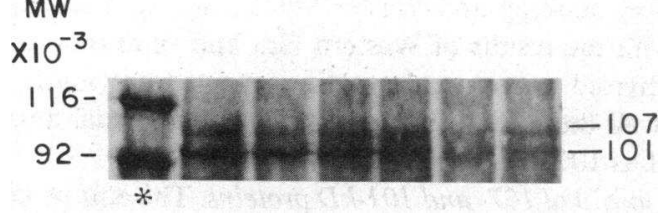

b

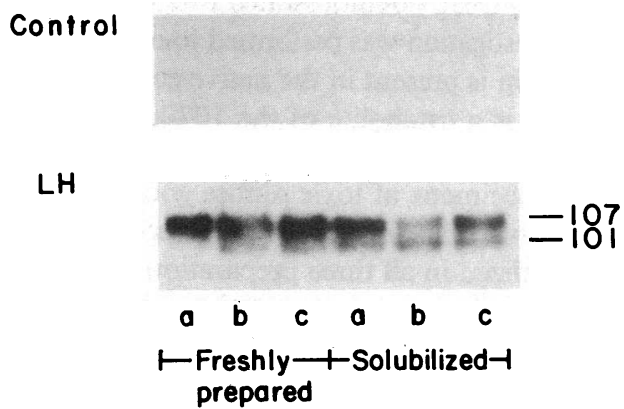

Figure 4. 101,000-mol-wt protein may be a degradative product of 107,000-mol-wt protein. Freshly prepared microsomes and Triton X100 -solubilized microsomes were kept at $-20^{\circ} \mathrm{C}$ (lanes $a$ ) or incubated at room temperature with (lanes $c$ ) or without (lanes $b$ ) a mixture of protease inhibitor: $1 \mathrm{mM}$ PMSF, $10^{-7} \mathrm{M}$ pepstatin A, and 5 mM EDTA. $50 \mu \mathrm{g}$ of these proteins were analyzed by SDS PAGE (6\%), stained with Coomassie Blue, and Western-blotted against control or patient L.H. sera.

* Molecular weight (MW) markers.
$101-\mathrm{kD}$ protein after $2 \mathrm{~d}$ of incubation. The effect of nonspecific protease inhibitor was also observed (Fig. 4 lane $c$ ). A mixture of $1 \mathrm{mM}$ phenylmethylsulfonyl fluoride (PMSF), $10^{-7}$ pepstatin $A$, and $5 \mathrm{mM}$ EDTA was used as protease inhibitor. The decrease of the $107-\mathrm{kD}$ protein was inhibited by the protease inhibitors, but inhibition of increase of $101-\mathrm{kD}$ protein was less certain. Triton X-100 itself did not affect the result of SDS PAGE or Western blot of 107-kD proteins (data not shown).

Investigation of the relationship between reduced and unreduced conditions of Western blot. The data described above suggest that microsomal antigen is composed of only the 107- and $101-\mathrm{kD}$ proteins. However, poorly defined large molecular mass proteins are stained by microsomal antibody in Western blots of proteins run under unreduced conditions (Fig. $5 a$ ). If the microsomal antigen is composed of only $107-\mathrm{kD}$ protein, these large molecular mass proteins should contain $107-\mathrm{kD}$ protein. Gels containing those large proteins were divided into four pools according to molecular mass. The proteins were eluted electrophoretically from the gel and analyzed by SDS PAGE and Western blot in reducing conditions (Fig. 5, $b$ and $c$ ). All large molecular mass protein pools contained 107-kD protein, which could be demonstrated both by silver staining and Western blot using patient L.H.'s serum, although not all large molecular mass antigen was converted to the $107-\mathrm{kD}$ form.

To determine whether renaturation of disulfide bonds of the 107-kD protein could occur, 107-kD protein was extracted from

a
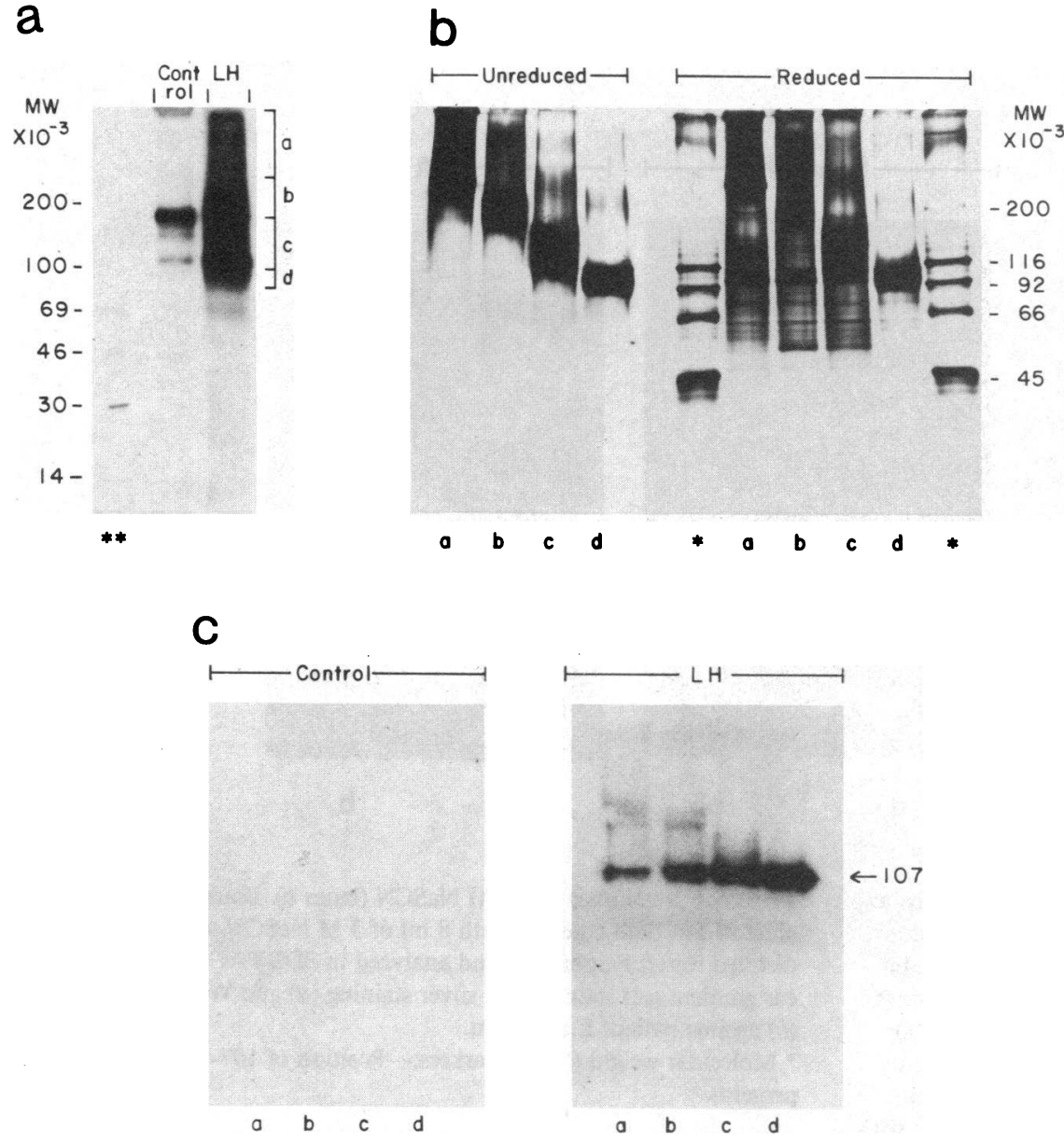

Figure 5. Poorly defined large molecular mass proteins visualized in Western blots run under nonreducing conditions contain $107-\mathrm{kD}$ protein. (a) $50 \mu \mathrm{g}$ of microsomal proteins were electrophoresed in SDS PAGE (3.3-20\%, linear gradient gel) in nonreducing condition, transferred onto nitrocellulose sheets, and incubated with control and patient L.H.'s sera. Bound antibody was visualized with ${ }^{125}$ I-protein A followed by autoradiography. The bands visible in the control sera lane represent ${ }^{125} \mathrm{I}$-protein A binding to microsomal proteins directly, because they are found when serum is omitted from the procedure. (b) Proteins corresponding to lanes $a, b, c$, and $d$ in 1) were electroeluted from $3.0 \mathrm{mg}$ of microsomal proteins run on $6 \%$ preparatory SDS PAGE. Each fraction was analyzed in SDS PAGE (3.3-20\%) under reducing or nonreducing conditions. Gel was stained with silver staining. (c) Proteins electrophoresed in reduced condition were analyzed by Western blot against control or patient L.H. sera. Onetenth and one-fourth of each protein fraction were used for silver staining and Western blot, respectively.

* Molecular weight ( $M W$ ) markers. ** Radioactive molecular weight $(M W)$ markers. 
SDS polyacrylamide gels in which microsomes had been electrophoresed in reducing conditions. This protein was incubated in PBS at room temperature for $1 \mathrm{~h}$ and then analyzed by SDS PAGE and Western blot under nonreducing conditions (Fig. 6). In comparison with the SDS PAGE of $107-\mathrm{kD}$ protein run under reducing condition, poorly defined large molecular mass proteins of $\sim 220-\mathrm{kD}$ were observed. These data suggest that microsomal antigen can exist as a complex or multimer of the $107-\mathrm{kD}$ protein.

Two-DG electrophoresis of 107-kD protein. Deoxycholatesolubilized microsomes were submitted to 2-DG electrophoresis. When the $\mathrm{pH}$ range of the first dimension of isoelectric focusing was narrow (pH 6.8-4.3), 107- and 101-kD antigenic proteins were demonstrated at around $\mathrm{pH} 6.8$ by Coomassie Blue staining and Western blot against patient L.H.'s serum (data not shown). The 107-kD protein was submitted to 2-DG electrophoresis (Fig. 7). The $107-\mathrm{kD}$ proteins separated into three components in the gel stained by silver staining. $A$ in Fig. 7 was demonstrated to have strong antigenicity by Western blot, and $B$ also had antigenicity, confirmed in two experiments. The isoelectric point (pI) of $A$ protein was 7.0. Specificity of the binding of antibody to these proteins was shown, since only $107-$ and $101-\mathrm{kD}$ proteins were visualized by Western blot of microsomal proteins run on the second dimension of the same gel. The data suggest that this $A$ protein is the microsomal antigen which has been purified essentially to homogeneity.

\section{Discussion}

We previously reported that a $107-\mathrm{kD}$ protein from thyroid microsomes can be identified as microsomal antigen by Western

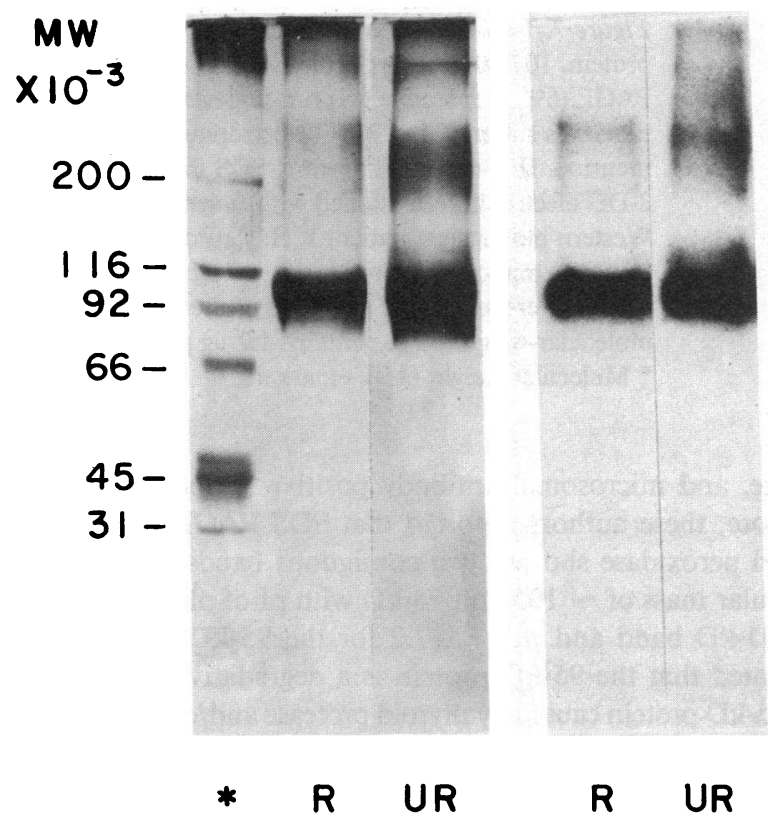

Figure 6. Effect of removal of reducing agent on SDS PAGE $(A)$ and Western blot $(B)$ of 107,000-mol-wt protein. 107,000-mol-wt protein was extracted from SDS PAGE (3.0 mm thick, 6\% preparatory gel) of reduced microsomal proteins $(3.0 \mathrm{mg})$. One-eighth of the extracted protein was left in PBS at room temperature for $1 \mathrm{~h}$ and then analyzed by SDS PAGE (3.3-20\%), stained with silver staining, and Western blotted against patient L.H.'s serum in reducing (lanes $R$ ) or nonreducing (lanes $U R$ ) conditions.

* Molecular weight $(M W)$ markers. blotting and immunoprecipitation studies (7). In this report, affinity chromatographic analysis also demonstrated that the 107$\mathrm{kD}$ protein and a related $101-\mathrm{kD}$ form are the microsomal antigen, and that no other protein is recognized as a specific antigenic protein. These data strongly suggest that microsomal antigen is composed of a predominant $107-\mathrm{kD}$ protein. However, each method has some imprecision. Western blot analysis has the advantage that the microsomal antigen can be separated from other proteins by detergent, reducing agent, and electric charge, but the protein may not be renatured. If the antibody recognizes an epitope that contains separate peptides, the antigen might not be recognized, even if the separated peptides are renatured (12). In fact, only 23 of 96 patients with microsomal hemagglutination test titer $>25,000$ had antibody against the $107-\mathrm{kD}$ protein in Western blots (17). However, the sera did not consistently bind any other protein.

The advantage of immunoprecipitation and affinity chromatography is that antigen can be used in the native condition. Therefore, all protein components of microsomal antigen should be detected, but the antigen may easily form aggregates with other nonspecific proteins, even in the presence of detergents. Antigenic proteins were stained as a smear in Western blot studies using denaturing but unreduced conditions for SDS PAGE (17). Consequently, in the immunoprecipitation study, a high background was observed, and in affinity chromatographic studies, numerous nonspecific proteins were eluted. Another possible disadvantage of immunoprecipitation of ${ }^{125} \mathrm{I}$-microsomes is that all the protein components of the microsomal antigen may not be iodinated. In this study, another antigenic protein with a molecular weight of $101 \mathrm{kD}$ was disclosed. However, 101-kD protein may be a degradative product because little $101-\mathrm{kD}$ protein was present in freshly prepared microsomes, and it increased in vitro. During solubilization by Triton X-100, various proteases may be released from microsomal vesicles. Because the increase of $101-\mathrm{kD}$ protein could not be clearly inhibited by protease inhibitors used in this study, it cannot be proven that the 101$\mathrm{kD}$ protein is a proteolytic metabolite of $107-\mathrm{kD}$ protein. In any case, only the $107-\mathrm{kD}$ protein was recognized as a specific antigenic protein by both methods.

The $107-\mathrm{kD}$ protein probably does not represent the native state of the antigen. Western blots of PAGE run under nonreducing conditions showed that poorly defined high molecular mass proteins have antigenic activity. In experiments in which $107-\mathrm{kD}$ protein extracted from SDS polyacrylamide gel was reanalyzed in SDS PAGE and Western blots run under nonreducing conditions, poorly defined large molecular mass proteins of $\sim 220 \mathrm{kD}$ were identified. Thus the microsomal antigen may be a complex or disulfide linked multimer of $107-\mathrm{kD}$ protein. In Western blots of gels run under nonreducing conditions, the $107-\mathrm{kD}$ protein may have linked randomly with other nonspecific proteins, because the proteins stained as a smear contained the $107-\mathrm{kD}$ protein. Recent studies in other laboratories on immunoprecipitation of microsomal antigen also suggest that microsomal antigen is a $105-\mathrm{kD}$ protein with intra-chain disulfide bonds (18) or contains two components (108 and $118 \mathrm{kD})$ that may be linked by noncovalent bonds to form a single protein of $230 \mathrm{kD}$ (18). However, the 108-kD component could be a degradative product of the $118-\mathrm{kD}$ protein, because SDS-solubilized microsomes were used in this study.

By using 2-DG electrophoresis, the $107-\mathrm{kD}$ antigenic protein $(A)$ was isolated, and its pI was found to be 7.0. In addition, a small $B$ protein was demonstrated to have antigenicity. The cause 

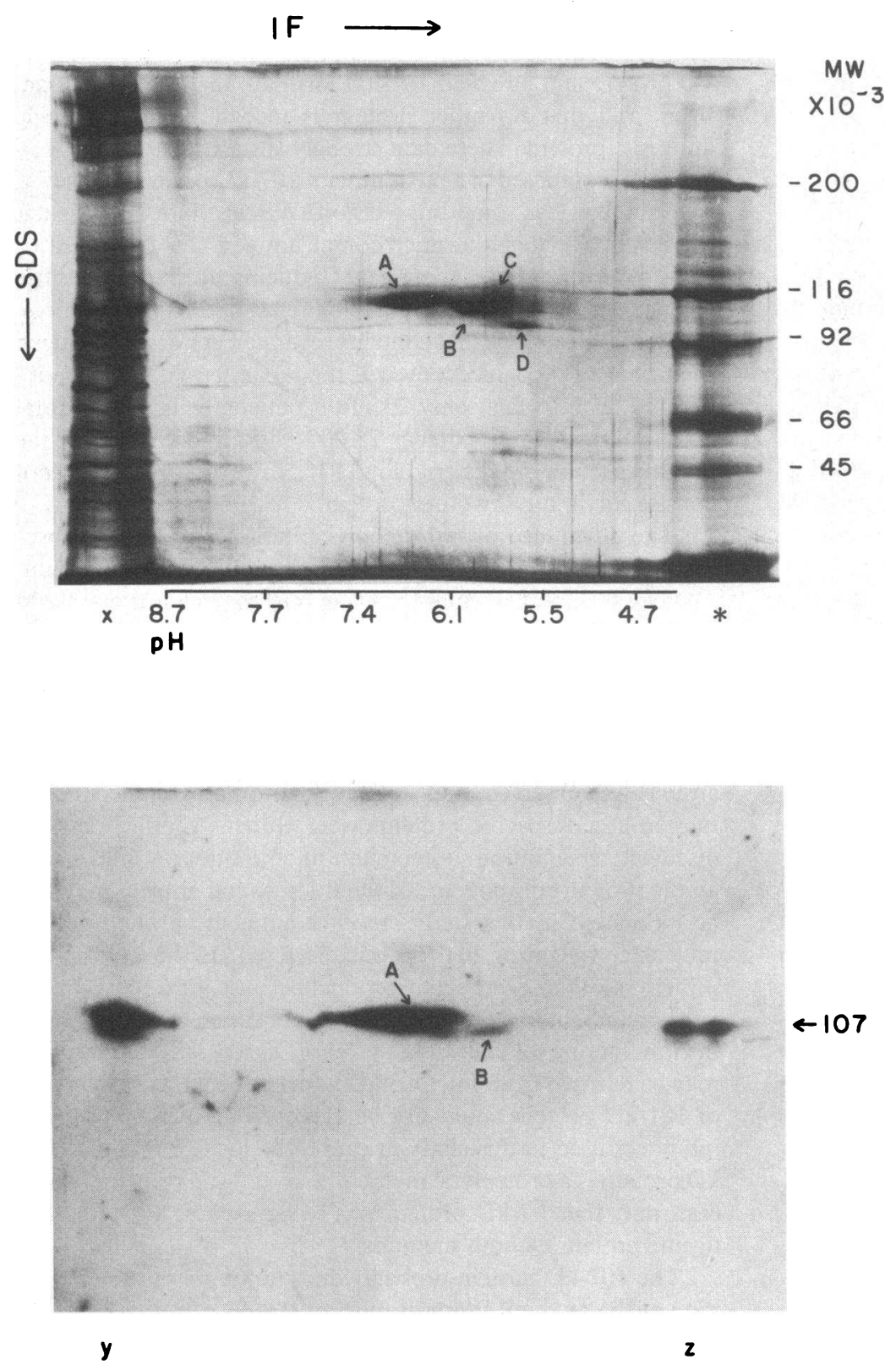

Figure 7. Two-DG electrophoresis of 107,000-mol-wt protein. 107,000-mol-wt protein extracted from SDS PAGE (6\%, preparative gel) run under reducing conditions was submitted to 2-DG electrophoresis. First dimension, IF. Second dimension, SDS PAGE (6\%). (a) 2-DG electrophoresis stained with silver staining. (b) Western blot against patient L.H. serum. $x, y$, and $z$, Reduced microsomal proteins $(x, 20 \mu \mathrm{g} ; y, 180 \mu \mathrm{g} ; z$, $120 \mu \mathrm{g})$ were applied at the edges of the 2-DG. Each molecular-weight band contains $1.2 \mu \mathrm{g}$ protein.

* Molecular weight $(M W)$ markers. of this heterogeneity has not been defined. It could be secondary to in vivo modifications, such as phosphorylation, acetylation, or addition of charged carbohydrate groups, or it could be due to artifactual modification (14). In this experiment, only 107$\mathrm{kD}$ proteins were submitted to 2-DG electrophoresis for further separation of the specific antigenic protein. The amount of 107$\mathrm{kD}$ protein applied was $1 / 16$ of $107-\mathrm{kD}$ proteins extracted from $3 \mathrm{mg}$ of microsomes and can be estimated to be 1-2 $\mu \mathrm{g}$ of protein by comparison with molecular weight marker proteins. This means that $A$ protein can be purified nearly enough for use in making antibodies, peptide mapping, etc.

Recently we found that an antibody immunoprecipitating thyroid peroxidase is present in sera of patients with AITD, and it is closely related to the microsomal antibody (20). Czarnocka et al. also (21) reported a similar possibility. Binding of a monoclonal antibody, directed against thyroid peroxidase, to thyroid cell membrane was inhibited by thyroid peroxidase, lactoper- oxidase, and microsomal antibody positive patient sera. Furthermore, these authors reported that SDS PAGE of purified thyroid peroxidase showed two contiguous bands of apparent

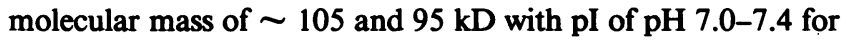
the $105-\mathrm{kD}$ band and $\mathrm{pH} 7.5-7.2$ for the $95-\mathrm{kD}$ band. They speculated that the $95-\mathrm{kD}$ protein is a degradative product of the $105-\mathrm{kD}$ protein caused by thyroid protease and/or glycosidase action. Furthermore, two other groups have reported $(22,23)$ that the molecular mass of thyroid peroxidase is $100-104 \mathrm{kD}$. All of this data indicates a close relation between thyroid peroxidase and microsomal antigen.

\section{Acknowledgments}

This work was supported in part by United States Public Health Service grants AM13377 and AM27384. 


\section{References}

1. Fagraeus, A., and J. Jensson. 1970. Distribution of organ antigens over the surface of thyroid cells as examined by the immunofluorescence test. Immunology. 18:413-416.

2. Fenzi, G. F., L. Bartalena, L. Chiovato, C. Marcocci, C. M. Rotella, R. Zonefrati, R. Toccafondi, and A. Pinchera. 1982. Studies on thyroid cell surface antigens using cultured human thyroid cells. Clin. Exp. Immunol. 47:336-344.

3. Khoury, E. L., L. Hammond, G. F. Bottazo, and D. Doniach. 1981. Presence of the organ-specific microsomal autoantigen on the surface of human thyroid cells in culture: its involvement in complement mediated cytotoxicity. Clin. Exp. Immunol. 45:316-328.

4. Khoury, E. L., G. F. Bottazo, and I. M. Roitt. 1984. The thyroid microsomal antibody revisited, its paradoxical binding in vivo to the apical surface of the follicular epithelium. J. Exp. Med. 159:577-591.

5. Roitt, I. M., N. R. Ling, D. Doniach, and K. G. Couchman. 1964. The cytoplasmic auto-antigen of the human thyroid. I. Immunological and biochemical characteristics. Immunology. 7:375-393.

6. Belyavin, G., and W. R. Trotter. 1959. Investigations of thyroid antigens reacting with Hashomoto sera, evidence for an antigen other than thyroglobulin. Lancet. 1:648-652.

7. Hamada, N., C. Grimm, H. Mori, and L. J. DeGroot. 1985. Identification of a thyroid microsomal antigen by Western blot and immunoprecipitation. J. Clin. Endocrinol. Metab. 61:120-128.

8. Mariotti, S., A. Pinchera, C. Marcocci, P. Vitti, C. Urbano, L. Chiovato, M. Tosi, and L. Baschieri. 1979. Solubilization of human thyroid microsomal antigen. J. Clin. Endocrinol. Metab. 48:207-212.

9. Markwell, M. K., S. M. Haas, N. E. Tolbert, and L. L. Bieber. 1981. Protein determination in membrane and lipoprotein samples: manual and automated procedures. Methods Enzymol. 72:296-303.

10. Bensadoun, A., and O. Weinstein. 1976. Assay of proteins in the presence of interfering materials. Anal. Biochem. 70:241-250.

11. Schardt, C. W., S. M. McLachlan, J. Matheson, and B. R. Smith, 1982. An enzyme-linked immunoassay for thyroid microsomal antibodies. J. Immunol. Methods. 55:155-168.

12. Tsang, V. C. W., J. M. Peralta, and A. R. Simons. 1983. Enzymelinked immunoelectrotransfer blot techniques (EITB) for studying the specificities of antigens and antibodies separated by gel electrophoresis. Methods Enzymol. 92:377-391.

13. Morrissey, J. H. 1981. Silver stain for proteins in polyacrylamide gels: a modified procedure with enhanced uniform sensitivity. Anal. Biochem. 117:307-310.

14. Kaderbhai, M. A., and R. B. Freedman. 1980. Two-dimensional gel electrophoresis of rat liver microsomal membrane proteins. Biochim. Biophys. Acta. 601:11-21.

15. O'Farrell, P. H. 1975. High resolution two-dimensional electrophoresis of proteins. J. Biol. Chem. 250:4007-4021.

16. Holloway, P. W. 1973. A simple procedure for removal of Triton X-100 from protein samples. Anal. Biochem. 53:304-308.

17. Hamada, N., N. Jaeduck, L. Portmann, K. Ito, and L. J. DeGroot. 1987. Antibodies against denatured and reduced thyroid microsomal antigen in autoimmune thyroid disease. J. Clin. Endocrinol. Metab. In press.

18. Banga, J. P., G. Pryce, L. Hammond, and I. M. Roitt. 1985. Structural features of the autoantigens involved in thyroid autoimmune disease: the thyroid microsomal/microvillar antigen. Mol. Immunol. 22: 629-642.

19. Kajita, Y., D. Morgan, A. B. Parkes, and B. R. Smith. 1985. Labeling and immunoprecipitation of thyroid microsomal antigen. FEBS (Fed. Eur. Biochem. Soc.) Lett. 187:334-338.

20. Portmann, L., N. Hamada, G. Heinrich, and L. J. DeGroot. 1985. Antithyroid peroxidase antibody in patients with autoimmune thyroid disease: possible identity with anti-microsomal antibody. J. Clin. Endocrinol. Metab. 61:1001-1003.

21. Czarnocka, B., J. Ruf, M. Ferrand, P. Carayon, and S. Lissitzky. 1985. Purification of the human thyroid peroxidase and its identification as the microsomal antigen involved in autoimmune thyroid diseases. FEBS (Fed. Eur. Biochem. Soc.) Lett. 190:147-152.

22. Pratt-Carlin, M. A. C., M. C. Eggo, A. Taurog, and G. N. Burrow. 1985. Immunodetection of thyroperoxidase in ovine thyroid cell culture. 67th Annual Meeting of the Endocrine Society, Baltimore, MD. Abstract No. 846.

23. Maeda, M., K. Umeki, K. Tomio, H. Nakagawa, and S. Ohtaki. 1985. Purification of thyroid peroxidase by immunoaffinity chromatography. 61st Annual Meeting of the Japan Endocrine Society. Abstract No. 339. 